\title{
Omnivorous Behaviour of the Agouti (Dasyprocta leporina): A Neotropical Rodent with the Potential for Domestication
}

\author{
Kegan Romelle Jones $\mathbb{D}^{1},{ }^{1,2}$ Kavita Ranjeeta Lall, ${ }^{2}$ and Gary Wayne Garcia ${ }^{2}$ \\ ${ }^{1}$ The Department of Basic Veterinary Sciences (DBVS), School of Veterinary Medicine (SVM), Faculty of Medical Sciences (FMS), \\ University of the West Indies (UWI), Mt. Hope, Trinidad and Tobago \\ ${ }^{2}$ The Open Tropical Forage-Animal Production Laboratory (OTF-APL), Department of Food Production (DFP), \\ Faculty of Food and Agriculture (FFA), The University of the West Indies (UWI), St. Augustine, Trinidad and Tobago \\ Correspondence should be addressed to Kegan Romelle Jones; keganjones11@gmail.com
}

Received 27 December 2018; Revised 26 March 2019; Accepted 4 April 2019; Published 2 May 2019

Academic Editor: Heide Schatten

Copyright ( $\odot 2019$ Kegan Romelle Jones et al. This is an open access article distributed under the Creative Commons Attribution License, which permits unrestricted use, distribution, and reproduction in any medium, provided the original work is properly cited.

\begin{abstract}
The agouti is a Neotropical rodent which is mainly utilized for its meat in rural communities. Recently, captive rearing of these animals by wildlife farmers have increased in the Neotropics. This short communication consists of observation of feeding behaviour of captive reared agoutis at the University of the West Indies Field Station in Trinidad and Tobago. This is the first time in Trinidad and Tobago that meat consumption and the omnivorous behaviour of the agouti have been documented in the literature. The consumption of chicken (Gallus domesticus) eggs, dead chickens, and a brown dove (Zenaida macroura) by captive reared agoutis was noted. This document described the omnivorous behaviour of the agouti which is primarily considered a frugivorous animal. Similar studies in South America have shown that wild and captive reared agoutis consumed animal matter. Further work must be done on the dietary needs and nutrient requirements of the agouti at different physiological states.
\end{abstract}

\section{Introduction}

The agouti is a Neotropical rodent has been reported to inhabit South America, Central America, Mexico, and the Caribbean Antilles [1]. These animals have been hunted for their meat in rural areas. It was one of the several species described as mini livestock which can be utilized by rural communities as an essential source of meat protein [2]. The agouti has been reared in captivity and has potential for domestication [1]. The authors have stated that the agouti diet consisted of mainly fruits and seed [3]. Other authors categorized the agouti as frugivores and herbivores [4].

There is a dearth information on the biology of the agouti, but recently in the Caribbean and South America, some research work has been conducted. Recently, a study on the anatomy of the digestive system has been done, and it was identified that the small intestines of the agouti were larger in comparison to the rabbit. These animals also had a large caecum which facilitates hindgut fermentation [5]. The preferred feed particle size in feeding agoutis was found to be $12.7 \mathrm{~mm} \times 25.4 \mathrm{~mm}$ for captive reared animals [6]. Gross anatomy of the male and female reproductive systems in the agouti was investigated in Trinidad; electroejaculation was performed in the male animal $[7,8]$. In South America, analysis of blood hormones (oestrogen and progesterone) and the oestrus cycle was investigated in the agouti, and the duration of the cycle was approximately 28 days [9]. Pathogen harboured by the agouti was reviewed but no apparent clinical effects on the animals were noted [10]. Gastrointestinal parasitic organisms were found in wild agoutis in Trinidad, but no effect on the animals' health or performance was observed $[11,12]$. Further work reviewed endoparasites of domesticated animals that originated from the Neotropics. These Neotropical animals had parasitic organisms present, but authors failed to report the effect but chose to only view these animals as reservoirs for diseases [13]. In captive reared animals, parasitic organisms have also been identified [14, 15], but no effects on the animals were 
reported either clinically or subclinically [16]. A parasite is defined as an organism which is present in the host and affects the host clinically or subclinically [17].

Recent works on blood parameters of agoutis have been reported, and there was no difference seen in blood reference values between male and female animals. However, there were differences in serum biochemical values among sexes $[16,18-21]$. If diets are to be formulated to feed these animals in captivity, then reference blood values will be essential in identifying the effect that diets will have on the agouti's performance. In the literature, the agoutis have been classified as frugivores, herbivores, or opportunistic feeders with little attention given on this animal's omnivorous behaviour. The manuscript attempts to report a situation where captive reared agoutis consumed chicken (Gallus domesticus) eggs, a dead chicken, and a brown dove (Zenaida macroura). Thus, the omnivorous behaviour of these animals which were historically given little attention is highlighted.

\section{Methodology}

2.1. Location and Climate. The University of the West Indies (UWI) Field Station is located at Mt. Hope, Trinidad $\left(10^{\circ} 38^{\prime} 16^{\prime \prime} \mathrm{N}\right.$ and $\left.61^{\circ} 25^{\prime} 41^{\prime \prime} \mathrm{W}\right)$. Trinidad and Tobago is located in the humid tropics with an average temperature of $32^{\circ} \mathrm{C}$ to $22^{\circ} \mathrm{C}$, rainfall of $1000 \mathrm{~mm}$, and humidity of $82 \%$.

\subsection{Housing of Agoutis at University Field Station (UFS).} At the location where the observations on the agoutis were made, animals were housed in cages and on floor pens. At that location, there were over one hundred agoutis at all physiological states being reared. The floor pens population consisted of both sexes, and the female to male ratio was $5: 1$. In the cages, animals are reared as breeding pairs (male and female), maternity (pregnant female), and juveniles (less than 3 months of age).

2.3. Diets of Agoutis at the University Field Station. The diet of the agoutis consisted of local feed resources such as mangoes (Mangifera indica), papaya (Carica papaya), green bananas (Musa spp.), pumpkin (Cucurbita pepo), guavas (Psidium guajava), breadfruit (Articarpus altilis), and dasheen (Colocasia esculenta). The agoutis' diet was also supplemented with Rabbit Ration ${ }^{\circledR}(17 \% \mathrm{CP})$ and chicken (Gallus domesticus) eggs.

\section{Results}

3.1. Observations of Captive Reared Agoutis. On $14^{\text {th }}$ October 2018 at 9:00 am before the animals in the floor pens were fed and cleaned, the observer noticed a live brown dove (Zenaida macroura) enter the pen. The observer entered the floor pen and took photographic evidence of the consumption of the brown dove by the adult female agouti. The dove landed in the water trough and was unable to fly because of its soaked feathers. The immobilized dove was then killed by an adult female.
Frank blood was seen on the floor of the pen where the dove was killed. The dove was held in the animal's mouth before the consumption of the carcass began (Figure 1). The female then proceeded to consume the dove using its forelimb to hold the carcass. To consume the carcass, the animal adopted the position similar to the consumption of fruits and seed (Figure 2). The animal ate the entire carcass including head and limbs, and the feathers of the bird remained on the floor. The consumption began at 9:10 am, and the carcass was consumed by 9:55 am.

The consumption of chicken eggs was similar to the consumption of fruits. The animal held the egg with its forelimbs. The eggs were cracked using their sharp incisors, and the egg shell and contents were consumed by the agouti (Figure 3). On a later date, the agoutis were fed fertile eggs and the agoutis ate the foetus, egg contents, and egg shells (Figure 4). All animals present in the unit at UFS were captive reared with an average age of six (6) years.

\section{Discussion}

This short communication showed that the Agouti (Dasyprocta leporina) consumed brown doves and chicken eggs (animal matter). It is the first time that agoutis in Trinidad have been reported to have consumed animal matter. Similar reports have been recorded in captivity where an agouti killed and consumed a male Liomys pictus [22]. The authors have described the agouti as a frugivore with major components of the diet comprising fruit and seeds [22]. However, animals in the order Rodentia have been described as omnivores with the majority of the animals in this order consuming fruits, seeds, animal matter, leaves, and fibre [23]. Omnivorous behaviour has been described for other members of the order Rodentia, but no records were made on Dasyprocta spp. [23]. The dentitions of members of the order Rodentia were described as having three functions which were cropping, insectivorousness, and flesh eating [23].

In Brazil, Dasyprocta leporina in the wild was reported to have consumed bruchid larvae found in palm nuts [24]. Further works reported that stomach contents of wild Dasyprocta leporina in French Guiana had 16.4\% animal matter [25]. There was no significant difference in the animal matter found in the stomach of the agouti at different times of the year [25]. Investigators in the French Guiana forest found agoutis' stomach containing an average of $6.2 \%$ animal matter (insects) [26].

In Tijuca National Park, a reintroduced female D. leporina was found eating carrion of a tapiti (Sylvilagus brasiliensis) [27]. The agouti ate the carrion in a similar manner to what was reported in this study. The carcass was held in the forelimbs, and the animal sat on in the hind limbs during consumption. The consumption of chicken eggs by the agouti in this report was also recorded in Brazil. Brazilian agoutis (Dasyprocta leporina and Dasyprocta azarae) which were reared in captivity with chickens (Gallas domesticus) and geese (Anas anas) consumed the eggs of both poultry species [28].

In Brazil, workers investigated the predatory behaviour of the agouti (Dasyprocta azarae). An experiment was set up 


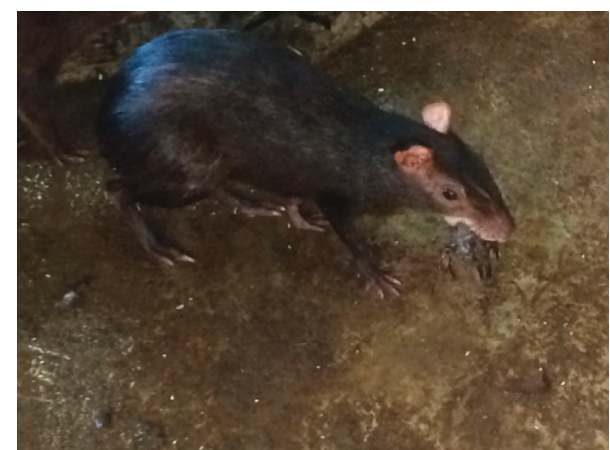

FIgUre 1: Female agouti holding dove (Zenaida macroura) in mouth before consumption at the University Field Station.

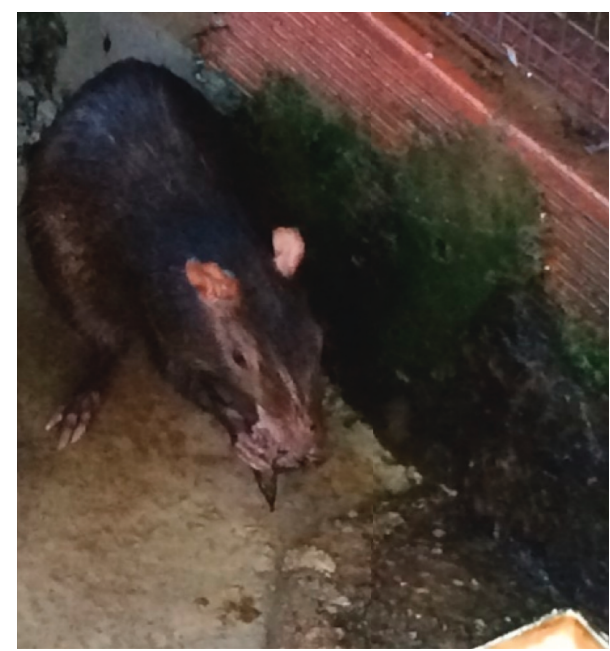

FIgURE 2: Female agouti consuming dove in a sitting position while manipulating carcass with forelimbs.

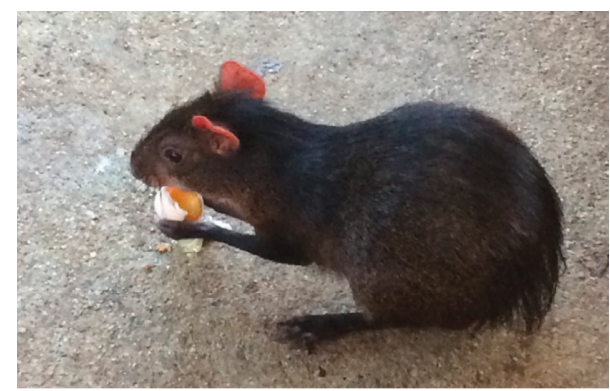

Figure 3: Agouti consuming chicken (Gallus domesticus) egg while assuming a sitting position.

using two groups of animals: the first group consisted of animals caught from the wild, while the second group was born in captivity. In both groups, immediate predation of eggs and chicks was noticed [29]. The results of the experiment in Brazil showed that the zoophagic behaviour in the agouti was innate which was similar to what was observed in this study. The animals present in this study were never given chicken (Gallas domesticus) eggs and were all born in captivity but when eggs were offered they consumed it immediately. Some authors in the review of the literature

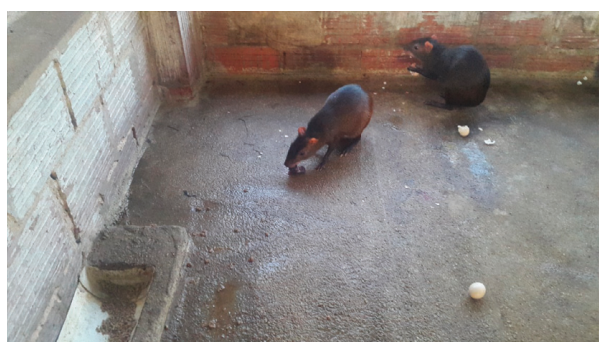

FIgURe 4: Agoutis consuming eggs with foetus inside. Animals consumed foetus, egg content, and shells.

stated these animals were frugivores with a capacity to be omnivorous due to their dental structure [30].

At this time, there is a dearth of information in the literature on the nutrient requirement of the agouti. In the Guianan forest, the lappes' (Agouti paca) diet contained more fruit, seed, and leaves than the agouti. However, the agouti consumed more insects than the lappe [26]. A preferential study on dietary items consumed by the lappe revealed that items with highest energy content were consumed more readily than feed items with lower energy content [31]. However, the study did not offer the lappe any animal matter but only fruits and vegetables. In Costa Rica, using teeth marking and faecal sampling, it was found that the lappe utilized approximately thirty-three (33) species of trees. However, the investigation did not identify the consumption of animal matter by the lappe [32]. The agouti and the lappe have been described as frugivores that consumed fruits, leaves, and seeds in their diets [33]. Similar work was done in Brazil, and the lappe was found to consume twelve species of trees belonging to ten families and ten genera [34].

Capybaras (Hydrochoerus hydrochaeris) reared in cultivated areas in Brazil consumed rice, corn, sugar cane, water hyacinth, and Brachiaria sp. [35]. A similar study was done on a biological reserve in Brazil, and the capybara was found to have consumed 133 species of herbaceous vegetation using faecal analysis and vegetation collection techniques [36]. A study in Argentina revealed that these animals selected plants based on their caloric energy content [36]. With respect to Neotropical rodents with the potential for domestication, the agouti (Dasyprocta leporina) has omnivorous feeding habits when compared to the lappe (Agouti paca/Cuniculus paca) which was found to be a strict frugivore and the capybara (Hydrochaerus hydrochaeris) was a strict herbivore.

\section{Conclusions}

Observation on the agoutis born in captivity in Trinidad and Tobago showed that they consumed a brown dove (Zenaida macroura), a dead chicken carcass, and chicken (Gallus domesticus) eggs. These findings were in agreement with previous observations in Brazilian literature which noted the zoophagic behaviour of the agouti (Dasyprocta leporina) in the wild and in captivity. However, this is the first time that this behaviour has been recorded in Trinidad and highlights the fact that these animals which were considered to be frugivores were actually omnivorous in feeding behaviour. 


\section{Future Directions}

If agoutis (Dasyprocta leporina) are to be reared in captivity for production, then the balanced diet of the animal must be known. Feeding trials must be conducted to evaluate the effect of diets containing different levels of the animal material (insects, meat, and eggs), fruits, seeds, and leaves to understand which composition is best for each physiological state.

\section{Data Availability}

The data used to support the findings of this study are included within the article.

\section{Conflicts of Interest}

The authors declare that there are no conflicts of interest.

\section{Acknowledgments}

This project was funded by the Campus Research and Publication Fund at the University of the West Indies.

\section{References}

[1] R. C. Brown-Uddenberg, G. W. Garcia, Q. S. Baptiste, T. Counand, A. O. Adogwa, and T. Sampson, The Agouti (Dasyprocta leporina, D. aguti) Booklet and Producers' Manual, GWG Publications, Champs Fleurs, Trinidad and Tobago, 2014, http://ostasp.brinkster.net/.

[2] J. Hardouin, E. Thys, V. Joiris, and D. Fielding, "Minilivestock breeding with indigenous species in the tropics," Livestock Research for Rural Development, vol. 15, no. 4, 2003.

[3] K. M. Silvius and J. M. V. Fragoso, "Red-rumped agouti (Dasyprocta leporina) home range use in an Amazonian forest: implications for the aggregated distribution of forest trees," Biotropica, vol. 35, no. 1, pp. 74-83, 2003.

[4] K. Lall, K. Jones, and G. Garcia, "Nutrition of six selected neotropical mammals in Trinidad and Tobago with the potential for domestication," Veterinary Sciences, vol. 5, no. 2, p. 52, 2018.

[5] G. W. Garcia, Q. S. Baptiste, A. O. Adogwa, M. Kakuni, K. Arishima, and T. Makita, "The digestive system of the agouti (Dasyprocta leporina) - gross anatomy and histology," Japanese Journal of Zoo and Wildlife Medicine, vol. 5, no. 1, pp. 55-66, 2000.

[6] B. Dookie, K. R. Jones, R. Mohammed, and G. W. Garcia, "Feed particle size preference and feed wastage in agouti (Dasyprocta leporina) reared intensively in the Republic of Trinidad and Tobago," Livestock Research for Rural Development, vol. 30, no. 11, 2018.

[7] W. M. Mollineau, T. Sampson, A. O. Adogwa, and G. W. Garcia, "Anatomical stages of penile erection in the agouti (Dasyprocta leporina) induced by electro-ejaculation," Anatomia, Histologia, Embryologia, vol. 41, no. 5, pp. 392394, 2012.

[8] D. M. Singh, A. Adogwa, W. Mollineau, and G. Garcia, "Gross and microscopic anatomy of the reproductive tract of the female agouti (Dasyprocta leporina): a neo-tropical rodent with potential for food production," Tropical Agriculture (Trinidad), vol. 91, no. 1, pp. 38-46, 2014.
[9] D. A. Guimaraes, R. L. Ramos, O. M. Ohashi, G. W. Garcia, and W. G. Vale, "Plasma concentration of progesterone and $17 \beta$-estradiol of black-rumped agouti (Dasyprocta prymnolopha) during the estrous cycle," Revista de Biología Tropical, vol. 59, no. 1, pp. 29-35, 2011.

[10] K. R. Lall, K. R. Jones, and G. W. Garcia, "Infectious diseases of six non-domesticated neo-tropical animals in Trinidad and Tobago," International Journal of Tropical Veterinary and Biomedical Research, vol. 3, no. 2, pp. 1-31, 2018.

[11] R. Lainson, L. A. Carneiro, and F. T. Silveira, "Observations on Eimeria species of Dasyprocta leporina (Linnaeus, 1758) (Rodentia: Dasyproctidae) from the state of Pará, North Brazil," Memórias do Instituto Oswaldo Cruz, vol. 102, no. 2, pp. 183-189, 2007.

[12] R. Suepaul, R. Charles, and F. Dziva, "Aerobic microflora and endoparasites of freshly shot agouti (Dasyprocta leporina) in Trinidad, West Indies," Journal of Zoo and Wildlife Medicine, vol. 47, no. 4, pp. 1044-1048, 2016.

[13] K. R. Jones and G. W. Garcia, "Endoparasites of domesticated animals that originated in the neo-tropics (new world tropics)," Veterinary Sciences, vol. 6, no. 1, p. 24, 2019.

[14] K. R. Jones and G. W. Garcia, "A survey of the gastrointestinal parasites present in the agouti (Dasyprocta leporina) intensively reared in Trinidad," Livestock Research for Rural Development, vol. 29, no. 10, 2017.

[15] K. R. Jones and G. W. Garcia, "A survey of the gastrointestinal parasites present in the agouti (Dasyprocta leporina) intensively reared in Trinidad, Republic of Trinidad and Tobago," Livestock Research for Rural Development, vol. 30, no. 10, 2018.

[16] K. R. Jones, K. R. Lall, and G. W. Garcia, "Haematological and serum biochemical reference values of healthy agoutis (Dasyprocta leporina) reared intensively in Trinidad, Republic of Trinidad and Tobago," Livestock Research for Rural Development, vol. 31, no. 1, 2019.

[17] K. R. Jones and G. W. Garcia, "Gastrointestinal parasites of domesticated animals introduced into the neo-tropics (new world tropics)," Concepts of Dairy and Veterinary Science, vol. 1, no. 2, 2018.

[18] E. E. A. Ribiero, M. C. S. Batista, M. A. M. Carvalho, and J. A. L. Silva, "Mineral and enzymatic level of healthy agoutis (Dasyprocta sp.) raised in captivity influenced by gender and age," Arquivo Brasileiro de Medicina Veterinaria e Zootecnia, vol. 60, no. 3, pp. 651-655, 2008.

[19] E. E. A. Ribiero, M. C. S. Batista, M. A. M. Carvalho, and J. A. L. Silva, "Hemogram and proteinogram of healthy agoutis (Dasyprocta sp.) raised in captivity influence of gender and age," Arquivo Brasileiro de Medicina Veterinaria e Zootecnia, vol. 60, no. 5, pp. 1123-1127, 2008.

[20] R. A. P. de Aquino, A. P. R. H. de Macedo, K. D. Filgueira, M. B. Bezerra, and V. V. de Paula, "Hematological parameters in captive agoutis (Dasyprocta sp.) in the Brazil's northeastern semiarid," Revista Cientíca de Medicina Veterinária Pequenos Animais e Animais de Estimacoa, vol. 7, no. 23, pp. 542-545, 2009.

[21] P. Nunes, O. Orozco, G. Estrada, and L. Luzcano, "Hemochemical and haematological indicators in Dasyprocta fuliginosa (Guara, Guatin o neque) in captivity," Revista de la Facultad de Medicina Veterinaria y de Zootecnia, vol. 53, no. 2, pp. 94-104, 2006.

[22] N. Smythe, "The natural history of the central American agouti (Dasyprocta punctata)," Smithsonian Contributions to Zoology, vol. 257, pp. 1-52, 1978. 
[23] S. O. Landry, "The Rodentia as omnivores," Quarterly Review of Biology, vol. 45, no. 4, pp. 351-372, 1970.

[24] K. M. Silvius, "Spatio-temporal patterns of palm endocarp use by three Amazonian forest mammals: granivory or 'grubivory'?," Journal of Tropical Ecology, vol. 18, no. 5, pp. 707-723, 2002.

[25] O. Henry, "Frugivory and the importance of seeds in the diet of the orange-rumped agouti (Dasyprocta leporina) in French Guiana," Journal of Tropical Ecology, vol. 15, no. 3, pp. 291-300, 1999.

[26] G. Dubost and O. Henry, "Comparison of diets of the acouchy, agouti and paca, the three largest terrestrial rodents of French Guianan forests," Journal of Tropical Ecology, vol. 22, no. 6, pp. 641-651, 2006.

[27] L. Figueira, R. Zucaratto, A. S. Pires, B. Cid, and F. A. S. Fernandez, "Carrion consumption by Dasyprocta leporina (Rodentia: Dasyproctidae) and a review of meat use by agoutis," Brazilian Journal of Biology, vol. 74, no. 3, pp. 585-587, 2014

[28] L. O. Marcondes-Machado, "Agouti (Dasyprocta sp.) (Mammalia, Rodentia) predatory behaviour in capitivity; considerations about reintroduction," Revista do Instituto Florestal, vol. 21, no. 2, pp. 165-168, 2009.

[29] E. L. A. Montiero-Filho, T. C. C. Margarido, J. R. Pachaly, P. R. Manginin, F. Montiani-Ferriera, and R. R. Lange, "Comportamento zoofágico inato de cutias-Dasyprocta azarae Lichtenstein, 1823 (Rodentia: Mammalia)," Arquivos de Ciências Veterinárias e Zoologia da Universidade Paranaense, vol. 2, pp. 135-142, 1999.

[30] D. A. McWilliams, "Determinants of capture reared diets for the agouti (Dasyprocta spp.)," Veterinary Clinics of North America: Exotic Animal Practice, vol. 12, pp. 279-286, 2009.

[31] M. Laska, J. M. L. Baltazar, and E. R. Luna, "Food preference and nutrient composition in captive pacas, Agouti paca (Rodentia, Dasyproctidae)," Mammalian Biology, vol. 68, no. 1, pp. 31-41, 2003.

[32] H. Beck-King, O. von Helverson, and R. Beck-King, "Home range, population density and food resources of the Agouti paca (Rodentia: Agoutidae) in Costo Rica: a study using alternative methods," Biotropica, vol. 31, no. 4, pp. 675-685, 1999.

[33] G. Govino and D. Fielding, "Paca (Agouti paca) and agouti (Dasyprocta spp.)-mini-livestock production in Amazonas state of Venezuela: 1 biology," Tropicultura, vol. 19, no. 2, pp. 56-60, 2001.

[34] R. Zucaratto, R. Carrara, and B. K. S. Franco, "Dieta da paca (Cuniculus paca) usando métodos indiretos numa área de cultura agrícola na Floresta Atlântica brasileira," Biotemas, vol. 23, no. 1, pp. 235-239, 2010.

[35] G. A. Felix, I. C. Almeida Paz, U. Piovezan et al., "Feeding behavior and crop damage caused by capybaras (Hydrochoerus hydrochaeris) in an agricultural landscape," Brazilian Journal of Biology, vol. 74, no. 4, pp. 779-786, 2014.

[36] L. D. V. Borges and I. G. Corales, "Feeding habits of capybaras (Hydrochoerus hydrochaeris, Linnaeus 1766), in the ecological reserve of taim (ESEC-Taim)-South of Brazil," Brazilian Archives of Biology and Technology, vol. 50, no. 3, pp. 409-416, 2007. 

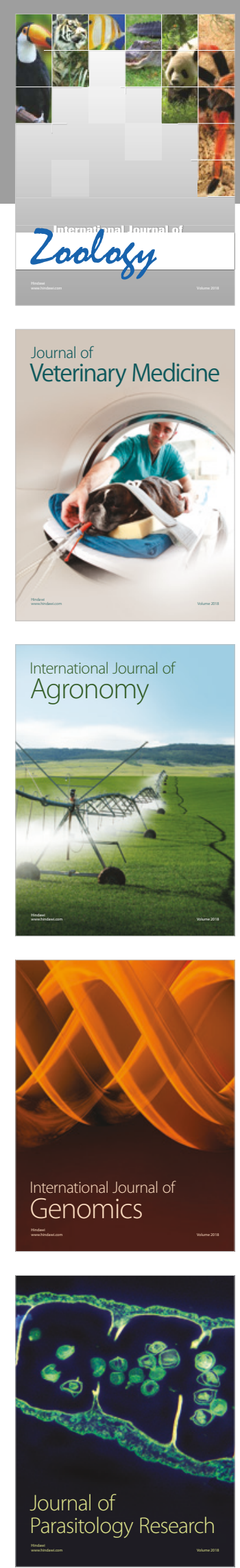

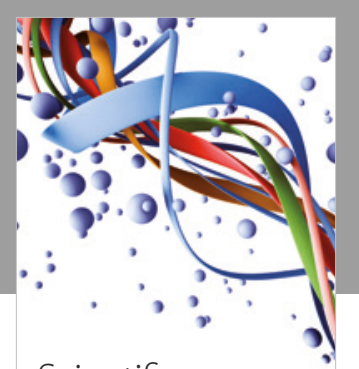

Case Reports in Veterinary Medicine Scientifica
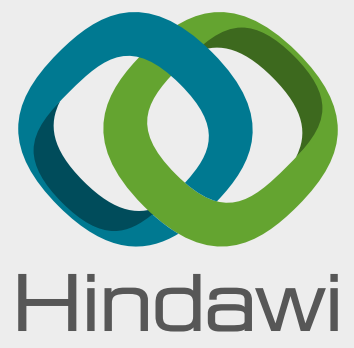

Submit your manuscripts at

www.hindawi.com
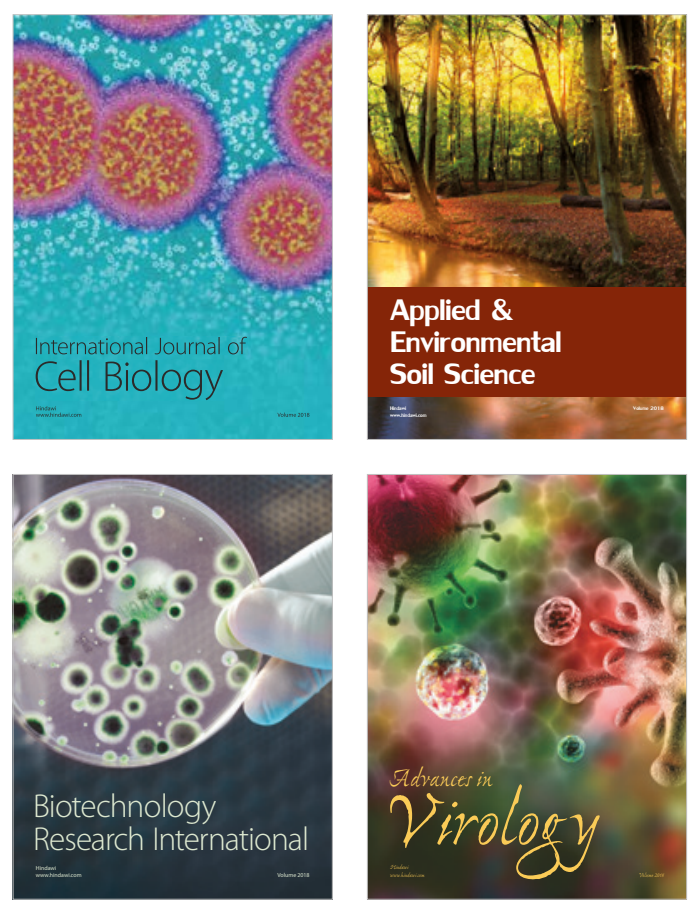

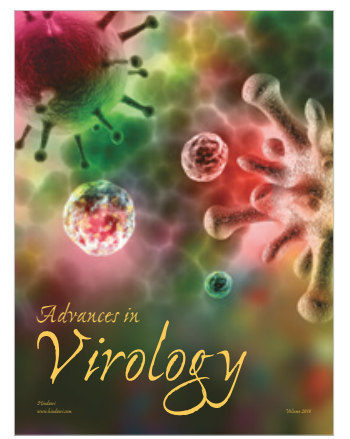

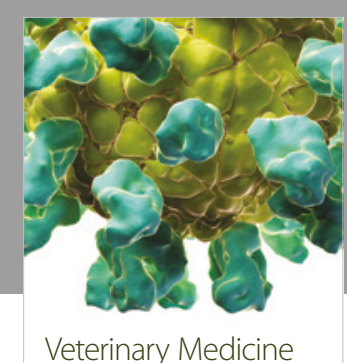
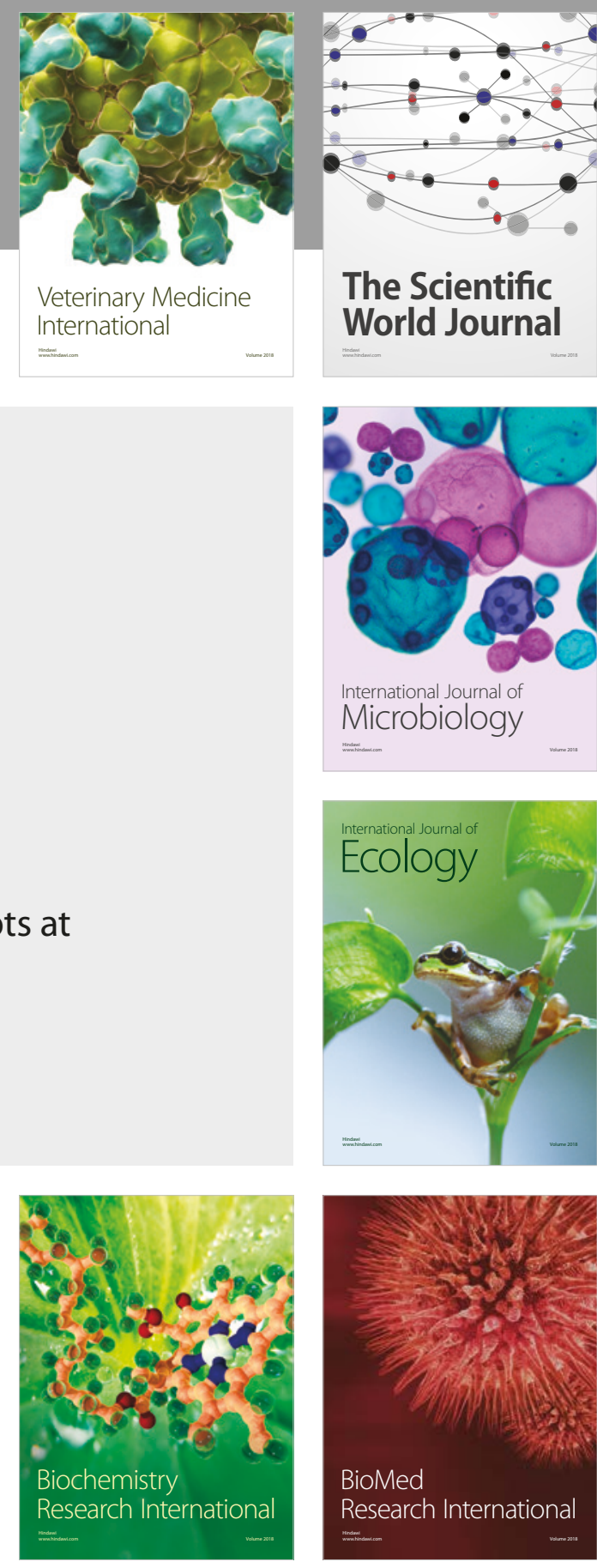

The Scientific World Journal

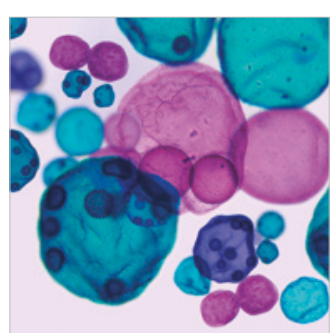

International Journal of Microbiology
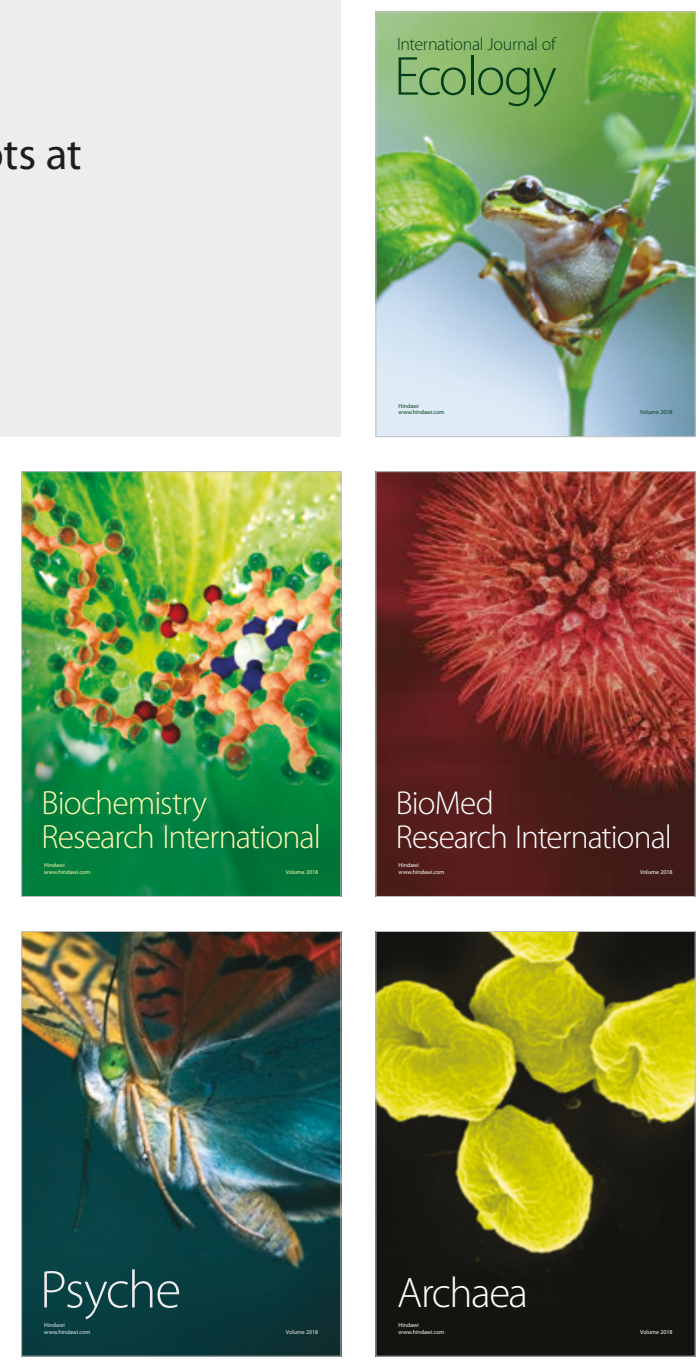